\title{
SAR of 4-Alkoxybenzoic Acid Inhibitors of the Trypanosome Alternative Oxidase
}

\author{
Alejandro Meco-Navas, ${ }^{\dagger, \perp}$ Godwin U. Ebiloma, ${ }^{\ddagger, \S, \perp}$ Ana Martín-Domínguez, ${ }^{\dagger}$ Irene Martínez-Benayas, ${ }^{\dagger}$ \\ Eduardo J. Cueto-Díaz, ${ }^{\dagger}$ Amani Saud Alhejely, Emmanuel O. Balogun, ${ }^{\ddagger}$ Machi Saito, ${ }^{\S}$ Miho Matsui, ${ }^{\S}$ \\ Natsumi Arai, ${ }^{\S}$ Tomoo Shiba, ${ }^{\S}$ Shigeharu Harada, ${ }^{\S}$ Harry P. de Koning, ${ }^{*}$, \\ and Christophe Dardonville*,†
}

${ }^{\dagger}$ Instituto de Química Médica, IQM-CSIC, Juan de la Cierva 3, E-28006 Madrid, Spain

${ }^{\ddagger}$ Institute of Infection, Immunity and Inflammation, College of Medical, Veterinary and Life Sciences, University of Glasgow, Glasgow G12 8QQ United Kingdom

${ }^{\S}$ Department of Applied Biology, Kyoto Institute of Technology, Kyoto 606-8585, Japan

"Department of Biochemistry, Ahmadu Bello University, Zaria 2222, Nigeria

Supporting Information

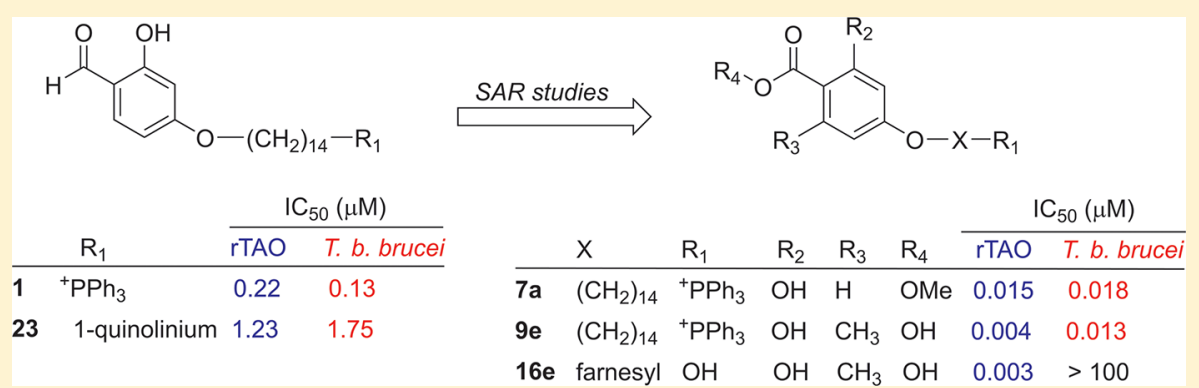

ABSTRACT: The SAR of 4-hydroxybenzaldehyde inhibitors of the trypanosome alternative oxidase (TAO), a critical enzyme for the respiration of bloodstream forms of trypanosomes, was investigated. Replacing the aldehyde group with a methyl ester resulted in a 10-fold increase in TAO inhibition and activity against T. brucei. Remarkably, two analogues containing the 2 hydroxy-6-methyl scaffold (9e and 16e) displayed single digit nanomolar TAO inhibition, which constitute the most potent 4alkoxybenzoic acid derivatives described to date. 9e was 50-times more potent against TAO and 10-times more active against T. brucei compared to its benzaldehyde analogue 1 . The farnesyl derivative 16e was as potent a TAO inhibitor as ascofuranone with $\mathrm{IC}_{50}=3.1 \mathrm{nM}$. Similar to ascofuranone derivatives, the 2-hydroxy and 6-methyl groups seemed essential for low nanomolar TAO inhibition of acid derivatives, suggesting analogous binding interactions with the TAO active site.

KEYWORDS: Trypanosome alternative oxidase (TAO) inhibitor, Trypanosoma brucei, lipophilic cation, 4-alkoxybenzoic acid derivative, triphenylphosphonium (TPP)

$\mathrm{T}$ he bloodstream forms (BSF) of African trypanosomes, which cause sleeping sickness in humans and animal trypanosomiasis (nagana) in livestock, rely exclusively on glucose metabolism for energy production. Lacking a functional oxidative phosphorylation pathway, BSF trypanosomes use the trypanosome alternative oxidase (TAO) as terminal oxidase to reoxidize the $\mathrm{NADH}$ that accumulates during glycolysis. TAO is a nonheme cyanide-insensitive membranebound di-iron protein that catalyzes the oxidation of ubiquinol and the four electron reduction of oxygen to water. ${ }^{1}$ This enzyme, which is essential for the respiration of BSF trypanosomes ${ }^{2}$ and is conserved among T. brucei subspecies, ${ }^{3}$ has been validated as a drug target against trypanosomes. ${ }^{4-7}$

In recent years, different series of TAO inhibitors have been reported that are based on the structure of the natural isoprenoid antibiotic ascofuranone (Figure 1). ${ }^{8-12}$ Kita's group reported the pharmacophore of ascofuranone ${ }^{8}$ and, shortly after, the 3-D structures of TAO in the presence and absence of ascofuranone derivatives, allowing a better understanding of inhibitor binding modes. ${ }^{13}$ However, to date ascofuranone is the only TAO inhibitor among the ascofuranone-based compounds that has shown in vivo curative activity in different mouse models of trypanosomiasis. ${ }^{6,14}$ The modest success of the ascofuranone-like inhibitors against $T$. brucei is attributed to the poor physicochemical (drug-like) properties of these compounds, as they are highly lipophilic and hardly soluble in water, resulting in poor pharmacokinetic properties. In these inhibitors, a high degree of lipophilicity is required not only for

Received: June 21, 2018

Accepted: July 31, 2018

Published: July 31, 2018 


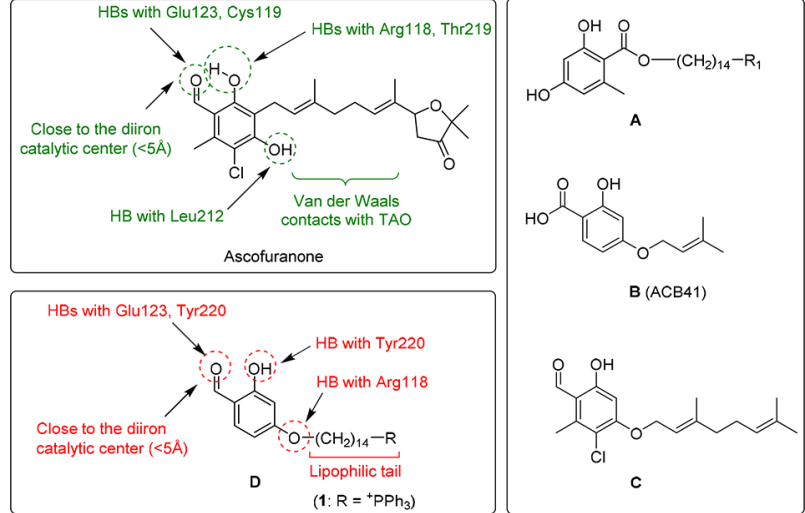

Figure 1. Structure of different TAO inhibitors chemotypes: ascofuranone, 4-hydroxybenzoates (A), ${ }^{15,16}$ 4-alkoxybenzoic acids (B) ${ }^{17}$ and 4-alkoxybenzaldehydes (C, D).${ }^{12,15}$ The main interactions of ascofuranone-like inhibitors with the TAO active site are shown in green color. ${ }^{8,13}$ The predicted main interactions of 4-alkoxybenzaldehyde $\mathbf{D}$ with the amino acids of the TAO active site ${ }^{15}$ are highlighted in red color. $\mathrm{HB}=$ hydrogen bond.

effective binding to $\mathrm{TAO}^{8}$ (i.e., a hydrophobic tail is necessary, Figure 1) but probably also to retain the inhibitors in the mitochondrial membrane where TAO is located. ${ }^{11}$ The requirement for these properties has hampered the search for inhibitors with drug-like properties.

Recently, we have developed different series of TAO inhibitors based on the 4-hydroxybenzoate and 4-alkoxybenzaldehyde chemotypes (Figure 1, A and D). These compounds displayed submicromolar to low nanomolar $\mathrm{IC}_{50}$ values against recombinant TAO (rTAO) and micromolar activities against T. brucei. The conjugation of these inhibitors with a mitochondrion-targeting lipophilic cation tail via a methylene linker yielded very potent trypanocides against wild-type and multidrug-resistant $T$. brucei strains. ${ }^{15,16}$ In particular, compound $\mathbf{A}\left(\mathrm{R}_{1}={ }^{+} \mathrm{PPh}_{3}, \mathrm{IC}_{50(\mathrm{rTAO})}=0.09 \mu \mathrm{M}\right)$ was able to reduce the parasite load of mice infected with $T$. $b$. brucei rhodesiense by intraperitoneal (ip) administration at $10 \mathrm{mg} / \mathrm{kg}$ (once daily for 4 days). ${ }^{15}$

In spite of the promising initial in vivo results, the benzoate derivatives A present several drawbacks: (1) a metabolic liability dependent on the substituents of the aromatic head (i.e., limiting the options for SAR development); (2) less than optimum water solubility; (3) a reduced therapeutic window in vivo (e.g., dosage $>4 \times 10 \mathrm{mg} / \mathrm{kg} / \mathrm{ip}$ was not tolerated, unpublished data). In contrast, the 4-alkoxy inhibitors (e.g., B-D), which are devoid of an ester bond, are expected to be resistant to serum hydrolases. In fact, compound $\mathbf{1}$ (Figure 1, D) proved to be stable in mouse serum although it appeared to bind serum proteins to a high degree. ${ }^{15}$ This behavior was attributed to the presence of the benzaldehyde group which may form Schiff's bases with the amino groups of the proteins.

In the current work, we further investigated the SAR of this promising TAO inhibitor scaffold by replacing the aldehyde group of $\mathbf{D}$ with a carboxylic acid (or ester), modulating the nature of the lipophilic tail (e.g., alkyl, geranyl, farnesyl) and of the substituent on the aromatic ring (Figure 2). In the designed compounds, the carboxylic acid function is expected to be in close proximity to the diiron center of TAO whereas the oxygen atom in the 4-position is expected to engage in hydrogen bond (HB) interactions with polar amino acids from the TAO binding site (e.g., Arg118) similarly to 1 (Figure 1,

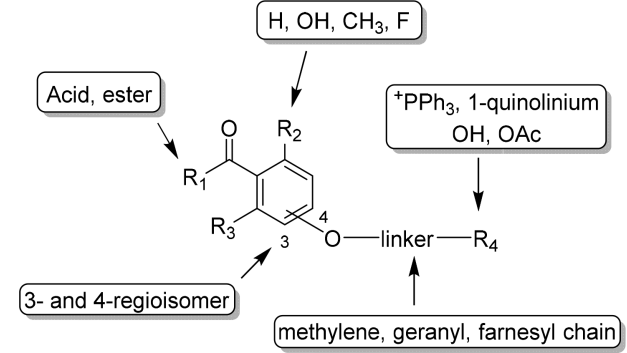

Figure 2. Structural modifications of 4-alkoxybenzoic acid derivatives studied in this work.

D). The presence of a free acid group in the molecule should enhance the water solubility of the molecules.

\section{RESULTS AND DISCUSSION}

The inhibitors with a lipocation alkyl tail (6a, 7a-e, 10b, 10c, and 10e) were synthesized in two steps starting from the corresponding 4-hydroxybenzoates $\mathbf{2 a - e}$ (Scheme 1). Alkylation of $2 \mathbf{a}$ with 1,10-dibromodecane and $\mathrm{NaHCO}_{3}$ gave the bromoalkoxy compound 4 a with low yield (22\%). Better yields of $5 \mathbf{a}-\mathbf{e}(43-67 \%)$ were obtained using the Mitsunobu protocol $^{18}$ with 14-bromotetradecan-1-ol (3). ${ }^{19}$ Nucleophilic substitution of these bromo derivatives with triphenylphosphine or quinoline yielded the phosphonium $(6 \mathbf{a}, 7 \mathbf{a}-\mathbf{e})$ and quinolinium salts $(\mathbf{1 0 b}, 10 \mathrm{c}, 10 \mathrm{10})$. Smooth hydrolysis of the ester function with potassium carbonate ${ }^{20}$ in $\mathrm{MeOH} / \mathrm{H}_{2} \mathrm{O}$ at $50{ }^{\circ} \mathrm{C}$ yielded the carboxylic acids $8 \mathbf{a}$ and $\mathbf{9 a}-\mathbf{e}$ with excellent yields. In contrast, the quinolinium salt $10 \mathrm{c}$ was hydrolyzed under acidic conditions ( $48 \%$ aqueous $\mathrm{HBr} / 60{ }^{\circ} \mathrm{C}$ ) to yield the acid derivative $11 \mathrm{c}$ (Scheme 1$)$. The TAO inhibitors with a farnesyl $(15 \mathbf{e})$ or geranyl $(17 \mathbf{a}-\mathbf{c}, 17 \mathbf{e})$ tail were synthesized from $2 \mathrm{a}-\mathrm{e}$ by the Mitsunobu reaction using alcohols 12 and 13 (Scheme 2). Treatment of $15 \mathbf{e}, 17 \mathbf{a}-\mathbf{c}$, and $17 \mathbf{e}$ with $\mathrm{KOH} / \mathrm{MeOH}$ at $60{ }^{\circ} \mathrm{C}$ led to complete hydrolysis of the acetate and benzoate groups to give high yields of the carboxylic acids 16e, 18a-c, and 18e. Selective hydrolysis of the acetate group of $17 \mathbf{a}-\mathbf{e}$ was performed with potassium carbonate to yield $19 \mathrm{a}-\mathbf{e}$, respectively.

The compounds were assayed as inhibitors of the ubiquinol oxidase activity of purified $\Delta$ MTS-TAO as described. ${ }^{15}$

Cationic TAO Inhibitors. The replacement of the aldehyde group of 1 by a methyl ester (7a) led to a 15-fold increase in TAO inhibition potency resulting in a 7 -fold improvement in activity against T. brucei (Table 1$)$. In this methyl ester series, replacement of the $2-\mathrm{OH}$ group by a fluorine (7b) or methyl substituent (7c) resulted in 50- and $>300$-fold decreased inhibition, respectively, compared with 7 a $\left(2-\mathrm{OH}>2-\mathrm{F} \gg 2-\mathrm{CH}_{3}\right)$. These data confirmed the need for a hydrogen bond-forming substituent at this position, for tight binding to TAO. As noted earlier with the 4-hydroxybenzoate series, ${ }^{15,16}$ a methylene linker of less than $\mathrm{C} 14$ was detrimental to TAO inhibition (compare 6a/7a). Switching the 4-alkoxy tail (7a) to the 3-position (7d) of the aromatic ring hardly influenced TAO inhibition ( 0.015 and $0.012 \mu \mathrm{M}$, respectively), which correlated with similar trypanocidal activities for both compounds ( 0.018 and $0.028 \mu \mathrm{M}$, respectively).

Interestingly, TAO inhibition was limited by the size of the ester substituent at $\mathrm{C} 1$ : an ethyl ester substituent was detrimental with a 60 -fold drop in inhibitor potency compared to the free acid (compare $7 e / 9 e, 15 e / 16 e$ ). The same trend was observed for the geranyl series (Table 2) with higher $\mathrm{IC}_{50}$ 
Scheme 1. Synthesis of TAO Inhibitors with a Lipocation Alkyl Tail ${ }^{a}$

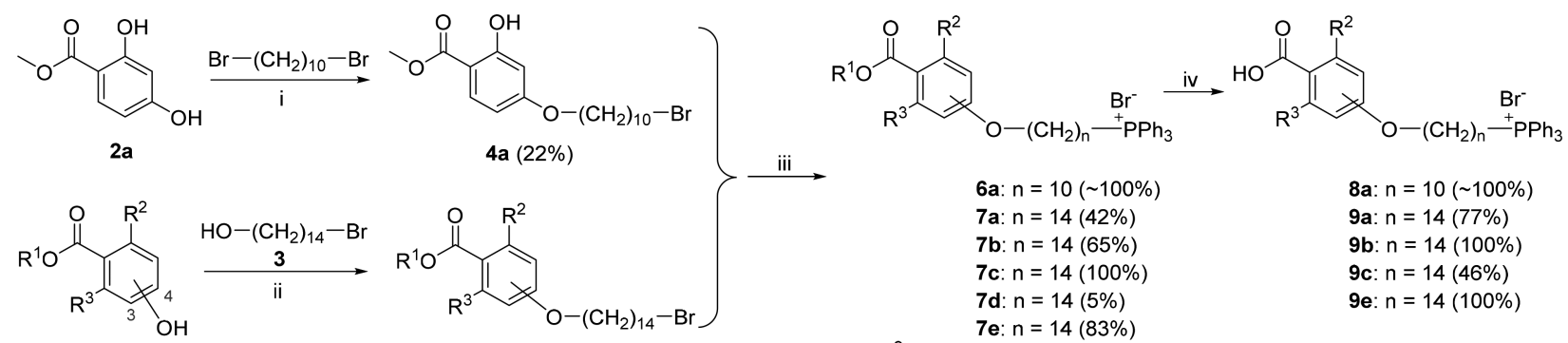

2a (4-OH): $\mathrm{R}^{1}=\mathrm{Me}, \mathrm{R}^{2}=\mathrm{OH}, \mathrm{R}^{3}=\mathrm{H}$ 2b $(4-\mathrm{OH}): \mathrm{R}^{1}=\mathrm{Me}, \mathrm{R}^{2}=\mathrm{F}, \quad \mathrm{R}^{3}=\mathrm{H}$ 2c $(4-\mathrm{OH}): R^{1}=M e, R^{2}=M e, R^{3}=H$ 2d (3-OH): $\mathrm{R}^{1}=\mathrm{Me}, \mathrm{R}^{2}=\mathrm{OH}, \mathrm{R}^{3}=\mathrm{H}$ 2e $(4-\mathrm{OH}): \mathrm{R}^{1}=\mathrm{Et}, \mathrm{R}^{2}=\mathrm{OH}, \mathrm{R}^{3}=\mathrm{Me}$

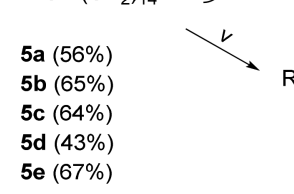

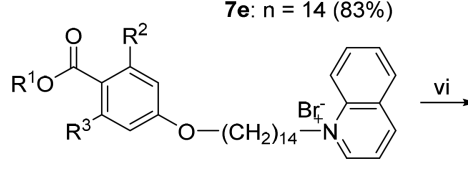

$10 \mathrm{~b}(36 \%)$ $10 \mathrm{c}(66 \%)$

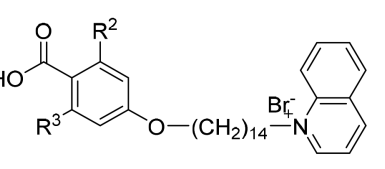

11c $(42 \%)$

${ }^{a}$ Reagents and conditions. (i) $\mathrm{NaHCO}_{3}, \mathrm{CH}_{3} \mathrm{CN}, 65^{\circ} \mathrm{C}$; (ii) DIAD, $\mathrm{Ph}_{3} \mathrm{P}$, THF, $0{ }^{\circ} \mathrm{C}$ to rt; (iii) $\mathrm{Ph}_{3} \mathrm{P}, \mathrm{CH}_{3} \mathrm{CN}, 80{ }^{\circ} \mathrm{C}$; (iv) (1) $\mathrm{K}_{2} \mathrm{CO}_{3}(3$ equiv), $\mathrm{MeOH} / \mathrm{H}_{2} \mathrm{O}(5 / 1)$ or $\mathrm{EtOH} / \mathrm{H}_{2} \mathrm{O}\left(5 / 1\right.$, for $7 \mathrm{e}$ ), $50{ }^{\circ} \mathrm{C}$, (2) $1 \mathrm{M} \mathrm{HCl}$; (v) Quinoline, $\mathrm{CH}_{3} \mathrm{CN}, 80{ }^{\circ} \mathrm{C}$; (vi) $\mathrm{HBr} 48 \%, \mathrm{H}_{2} \mathrm{O}, 60{ }^{\circ} \mathrm{C}$.

Scheme 2. Synthesis of TAO Inhibitors with a Geranyl or Farnesyl Tail ${ }^{a}$

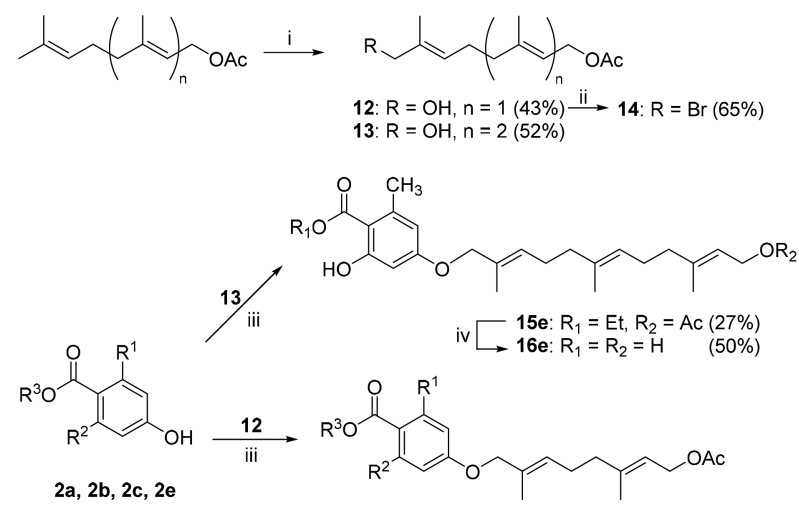

17a: $R^{1}=O H, R^{2}=H, \quad R^{3}=M e(49 \%)$

17b: $R^{1}=F, \quad R^{2}=H, \quad R^{3}=M e(64 \%)$

17c: $R^{1}=M e, R^{2}=H, \quad R^{3}=M e(68 \%)$

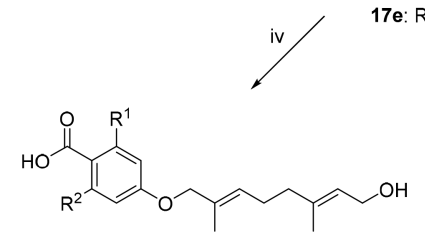

18a: $R^{1}=O H, R^{2}=H \quad(80 \%)$

18b: $R^{1}=F, \quad R^{2}=H \quad(86 \%)$

18c: $R^{1}=M e, R^{2}=H \quad(100 \%)$

18e: $R^{1}=O H, R^{2}=M e(84 \%)$

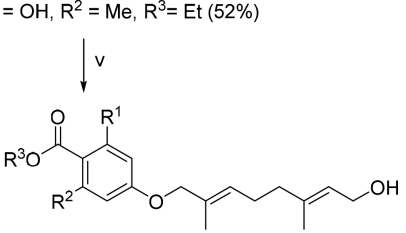

19a: $R^{1}=O H, R^{2}=H, \quad R^{3}=$ Me $(98 \%)$ 19b: $R^{1}=F, \quad R^{2}=H, \quad R^{3}=M e(83 \%)$ 19c: $R^{1}=M e, R^{2}=H, \quad R^{3}=M e(63 \%)$ 19e: $R^{1}=O H, R^{2}=M e, R^{3}=E t(83 \%)$
${ }^{a}$ Reagents and conditions. (i) (1) $\mathrm{SeO}_{2},{ }^{t} \mathrm{BuOOH}$, salicylic acid (cat.), $\mathrm{CH}_{2} \mathrm{Cl}_{2}, 30 \mathrm{~min}, \mathrm{rt}$; (2) geranyl acetate or farnesyl acetate, $45 \mathrm{~h}$, rt; (ii) $\mathrm{CBr}_{4}, \mathrm{Ph}_{3} \mathrm{P}, \mathrm{CH}_{2} \mathrm{Cl}_{2}$; (iii) $\mathrm{DIAD}, \mathrm{Ph}_{3} \mathrm{P}, \mathrm{THF}, 0{ }^{\circ} \mathrm{C}$ to rt; (iv) (1) $1 \mathrm{M} \mathrm{KOH}, \mathrm{MeOH}$ or EtOH (for 15e), $60{ }^{\circ} \mathrm{C}$, (2) $1 \mathrm{M} \mathrm{HCl}$; (v) $\mathrm{K}_{2} \mathrm{CO}_{3}, \mathrm{MeOH}$, rt (for 17a) or $\mathrm{K}_{2} \mathrm{CO}_{3}, \mathrm{EtOH}, 35^{\circ} \mathrm{C}$ (for $\mathbf{1 7 e}$ ).

values for the ethyl ester 19e $(>5 \mu \mathrm{M})$ compared to the free acid 18e $(2.4 \mu \mathrm{M})$. Intriguingly, replacement of the methyl ester $(7 \mathbf{a}$ and $7 \mathbf{b})$ or aldehyde group (1) at $\mathrm{C} 1$ by a carboxylic acid led to a drastic loss of inhibition $\left(\mathrm{IC}_{50}>5 \mu \mathrm{M}\right.$ for $9 \mathrm{a}$ and 9b). In contrast, the 2-hydroxy-6-methyl acid analogue 9e inhibited TAO in the low nanomolar range $\left(\mathrm{IC}_{50}=4.2 \mathrm{nM}\right)$ indicating that the presence of the 6-methyl substituent in $9 \mathrm{e}$ is playing a key role in the binding of inhibitors with an acid functional group, similar to the ascofuranone-based inhibitors. ${ }^{8}$
The triphenylphosphonium cation was more favorable than the 1-quinolinium cation for upper inhibition of TAO (compare $7 \mathbf{e} / \mathbf{1 0 e}, 7 \mathbf{b} / \mathbf{1 0 b})$. In this series of quinolinium salts, an aldehyde group at $\mathrm{C} 1\left(23, \mathrm{IC}_{50}=1.23 \mu \mathrm{M}\right)$ was superior to an ester or acid group $\left(\mathrm{IC}_{50}>5 \mu \mathrm{M}\right)$.

Noncationic Inhibitors with a Methylene, Geranyl, and Farnesyl Tail. The acid derivative 16e with a farnesyl lipophilic tail was the most potent inhibitor of this series $\left(\mathrm{IC}_{50}\right.$ $=3.1 \mathrm{nM}$ ), superior to the geranyl counterpart $18 \mathrm{e}$ and the rest of the geranyl acid derivatives $(\mathbf{1 8 a}-\mathbf{c})$ which were single digit micromolar inhibitors (Table 2). Remarkably, one extra isoprenyl unit (16e) was responsible for an increase in inhibition by 3 orders of magnitude within this series. In contrast, the benzoate derivatives (15e, 17a, 17c, 19b, 19e) were much less potent TAO inhibitors $\left(\mathrm{IC}_{50}>5 \mu \mathrm{M}\right)$, with the exception of $5 \mathrm{a}$ and $19 \mathrm{c}\left(\mathrm{IC}_{50} \approx 2 \mu \mathrm{M}\right)$. These inhibition values are in the same range as those of previously reported TAO inhibitors bearing a 4-alkoxy isoprenoid chain such as $\mathbf{B}$ (Figure $\left.1, \mathrm{ACB} 41, K_{\mathrm{i}}=5 \mu \mathrm{M}\right)^{17}$ or $\mathrm{C}\left(\mathrm{IC}_{50}=1 \mu \mathrm{M}\right){ }^{12,17} \mathrm{We}$ decided to study whether a geranyl tail would have the same (weak) effect on the inhibitory potency of the benzoate series derived from scaffold A. The benzoate derivative 20a with the geranyl tail at $\mathrm{C} 1$ was synthesized by reaction of 1 equiv of 2,4dihydroxybenzoic acid and 1 equiv of 14 in the presence of potassium carbonate in anhydrous acetone at $60{ }^{\circ} \mathrm{C}$. The product of dialkylation 21a was also isolated by silica chromatography (Scheme 3).

Compound 20a inhibited TAO in the low nanomolar range $\left(\mathrm{IC}_{50}=9.1 \mathrm{nM}\right)$, with a potency similar to that of its 14bromotetradecane benzoate analogue $(10.8 \mathrm{nM}) .{ }^{15}$ This result indicates that the geranyl tail is a valid bioisosteric replacement of the methylene tail for the 4-hydroxybenzoate inhibitor series (A) but it is less effective for the 4-alkoxybenzoic acid derivatives. Not surprisingly, the disubstituted derivative 21a with the 4-OH position blocked by the 4-alkoxygeranyl group inhibited TAO poorly $(>5 \mu \mathrm{M})$. The 4-hydroxybenzoate inhibitors are expected to bind TAO with the 4-OH group close to the diiron catalytic center, which is not possible with this disubstituted compound.

The trypanocidal activity of the new compounds was assessed against wild-type and multidrug-resistant strains of T. b. brucei. In the cationic series, the triphenylphosphonium 
Table 1. Biological Evaluation of 4-Alkoxybenzoate-Lipocation Conjugates against $\left.\mathrm{rTAO}_{(\mathrm{IC}}, \mu \mathrm{M}\right), \mathrm{T} . \boldsymbol{b} . \mathrm{brucei}\left(\mathrm{EC} \mathrm{C}_{50}, \mu \mathrm{M}\right)$, and Human Cells $\left(\mathrm{CC}_{50}, \mu \mathrm{M}\right)$

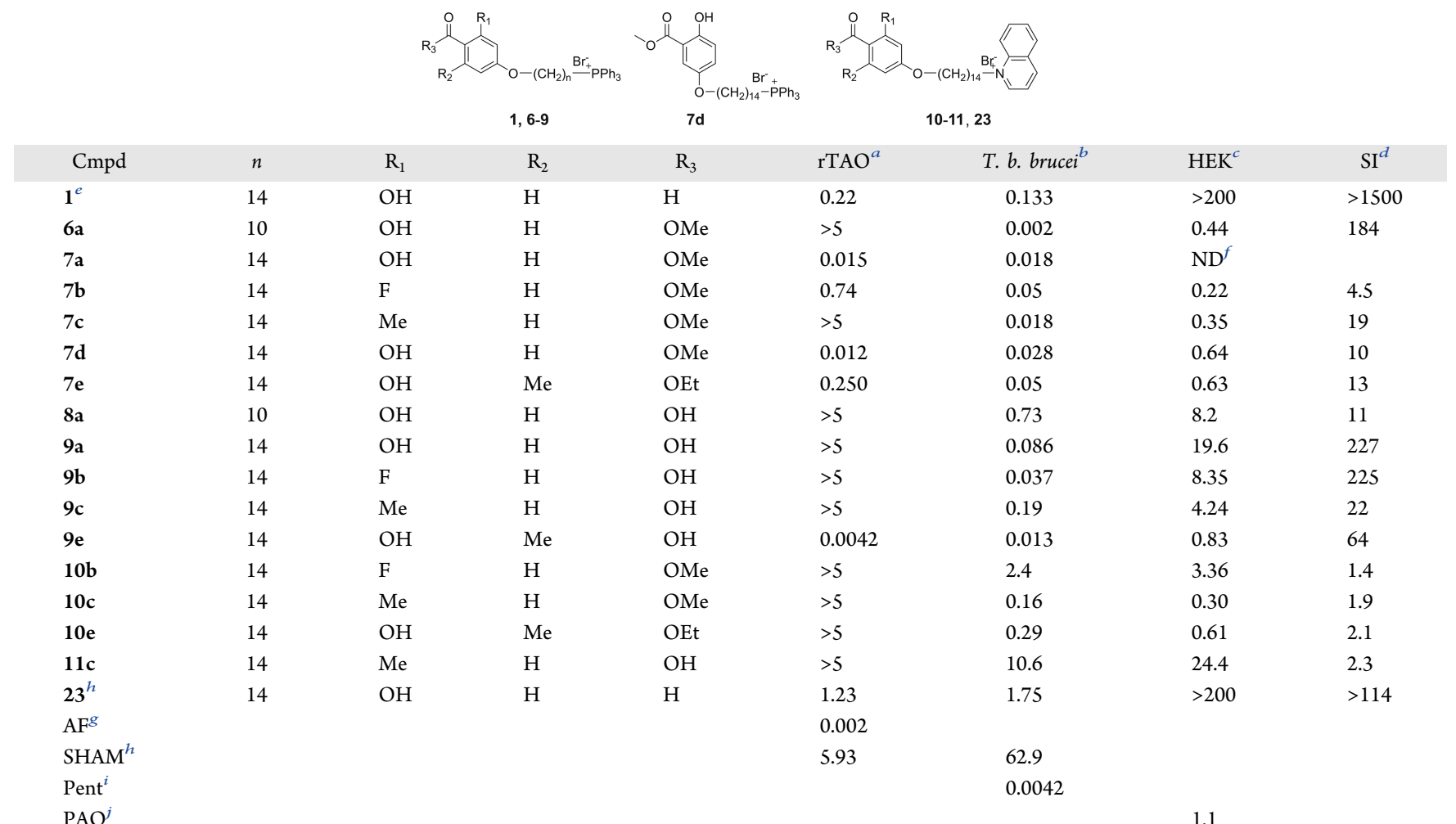

${ }^{a}$ Purified recombinant trypanosome alternative oxidase from T.b. brucei. ${ }^{b}$ Trypomastigotes of T.b. brucei s427. ${ }^{c}$ Cytotoxicity on human embryonic kidney cells. ${ }^{d}$ Selectivity index $=\mathrm{CC}_{50} / \mathrm{EC}_{50}\left(\mathrm{~T}\right.$. brucei WT). ${ }^{e}$ Taken from ref $15 .{ }^{f}$ Not determined. ${ }^{g}$ Ascofuranone. ${ }^{13}$ MIC value for ascofuranone: $30 \mathrm{nM}$ in the presence of glycerol, and $250 \mu \mathrm{M}$ under standard growth conditions. ${ }^{10}{ }^{h}$ Salicylhydroxamic acid. ${ }^{i}$ Pentamidine. ${ }^{j}$ Phenylarsine oxide. All the values represent the mean of 3 experiments \pm SEM (see ESI for SEM values).

conjugates $(7 \mathbf{b}, 7 \mathbf{c}, 7 \mathbf{e})$ were 6 - to 48 -times more potent than the quinolinium salts $(\mathbf{1 0 b}, \mathbf{1 0 c}, \mathbf{1 0 e}$; Table 1$)$, in agreement with previous results. ${ }^{15,16}$ However, the benzoate quinolinium salts $10 \mathrm{c}$ and $10 \mathrm{e}$ were 5 - to 10 -fold more potent than the benzaldehyde hit $23\left(\mathrm{EC}_{50}=1.75 \mu \mathrm{M}\right)$. Replacing the aldehyde group $\left(1, \mathrm{R}_{3}=\mathrm{H}\right)$ by a methyl ester function ( $7 \mathbf{a}$, $\left.\mathrm{R}_{3}=\mathrm{OMe}\right)$ resulted in a 7 -fold increase in trypanocidal activity against T. $b$. brucei. In this benzoate series, replacement of the $2-\mathrm{OH}$ with a $2-\mathrm{Me}(7 \mathrm{c})$ had no influence on the activity whereas a $2-\mathrm{F}(7 \mathbf{b})$ or $(2-\mathrm{OH}, 6-\mathrm{Me})$ substituent $(7 \mathbf{e})$ gave slightly less potent compounds (2.5-fold). The influence on trypanocidal activity of a free acid group in $\mathrm{R}_{3}$ depended on the nature of the substituents $R_{1}$ and $R_{2}$; the benzoate derivatives $7 \mathbf{b}\left(\mathrm{R}_{2}=\mathrm{F}, \mathrm{R}_{3}=\mathrm{H}\right)$ and $7 \mathbf{e}\left(\mathrm{R}_{2}=\mathrm{Me}, \mathrm{R}_{3}=\mathrm{OH}\right)$ were 1.4- to 4-times less active than the free acids $9 \mathbf{b}$ and $9 \mathbf{e}$, respectively. In contrast, the benzoates $7 \mathrm{a}\left(\mathrm{R}_{1}=\mathrm{OH}, \mathrm{R}_{2}=\mathrm{H}\right), 7 \mathrm{c}$ and $10 \mathrm{c}$ $\left(R_{1}=M e, R_{2}=H\right)$ were 5-, 10-, and 66-times more active than the free acids $9 a, 9 c$ and $11 c$, respectively.

The noncationic benzoate inhibitors with a geranyl or farnesyl tail holding an OAc group (15e, 17a, 17c) displayed low micromolar activity against $T$. brucei $(<20 \mu \mathrm{M})$. In contrast, the inhibitors with a free acid group $(\mathbf{1 8 a}-\mathbf{c}, \mathbf{1 8 e}$, 16e) were all inactive at the highest dose tested $(100 \mu \mathrm{M})$, possibly due to poor uptake of these negatively charged carboxylate compounds $\left(\mathrm{p} K_{\mathrm{a}}<5\right)$ into the trypanosomes' mitochondria. The benzoate derivatives with a 14-bromotetradecane chain $(\mathbf{5 a}-\mathbf{c})$ were inactive except $\mathbf{5 d}(8.1 \mu \mathrm{M})$ and 5e $(8.9 \mu \mathrm{M})$ which displayed $\mathrm{IC}_{50}<10 \mu \mathrm{M}$.
Little difference in trypanocidal activity was observed between WT and the multidrug resistant cell line B48 with resistance factors (RF) close to 1 (Tables S1), indicating they do not utilize the known drug transporters TbAT1 and HAPT. $^{21,22}$ In contrast, several inhibitors (5d, 5e, 8a, 9c, 9e, 10b, 20a) were more effective against the $T$. brucei cell line from which all three aquaporins were deleted (AQP1-3 triple $\mathrm{KO}^{23}$ ). These trypanosomes are particularly sensitive to TAO inhibitors because they cannot dispose of the glycerol produced in large quantity under anaerobic conditions (i.e., when TAO is inhibited). Accumulation of glycerol is toxic to the cells as a result of the inhibition of the glycerol kinase and depletion of ATP production. ${ }^{14,24}$ The same compounds were also significantly more effective against $T . b$. brucei WT $(\mathrm{RF}<$ 1) when coincubated with $5 \mathrm{mM}$ glycerol, which inhibits the anaerobic ATP production pathway (Tables S1). Analogous results were obtained with the benzaldehyde inhibitors $\mathbf{1}, \mathbf{2 2}$, and $23,{ }^{15}$ supporting the view that TAO is highly likely to be the main target of 5d, 5e, 8a, 9c, 9e, 10b, and 20a. In contrast, compounds $7 \mathbf{b}, 7 \mathbf{c}, 7 \mathbf{e}, 9 \mathrm{a}$, and $9 \mathbf{b}$ appeared to be less dependent on TAO inhibition as shown by the RF $>2$ against the AQP1-3 knockout line and against T. b. brucei WT +glycerol indicating that these compounds probably have multitarget activity (e.g., effect on mitochondrial membrane potential, mitochondrial $\mathrm{F}_{\mathrm{o}} \mathrm{F}_{1} \mathrm{ATPase}^{25}$ ). Cytotoxicity against HEK cells was low $(>20 \mu \mathrm{M})$ for the noncationic inhibitors with a geranyl (17a, 17c, 20a), farnesyl (15e), and methylene (5d, 5e) tail, and the cationic inhibitors with a free acid group $(8 \mathrm{a}, 9 \mathrm{a}-\mathrm{c})\left(\mathrm{CC}_{50}>4 \mu \mathrm{M}, \mathrm{SI}\right.$ from 11 to 227$)$. In contrast, the 
Table 2. Biological Evaluation of 4-Alkoxybenzoates with Alkyl, Geranyl, and Farnesyl Tail against rTAO $\left(\mathrm{IC}_{50}, \mu \mathrm{M}\right)$, T. b. brucei $\left(\mathrm{EC}_{50}, \mu \mathrm{M}\right)$, and Human Cells $\left(\mathrm{CC}_{50}, \mu \mathrm{M}\right)^{a}$
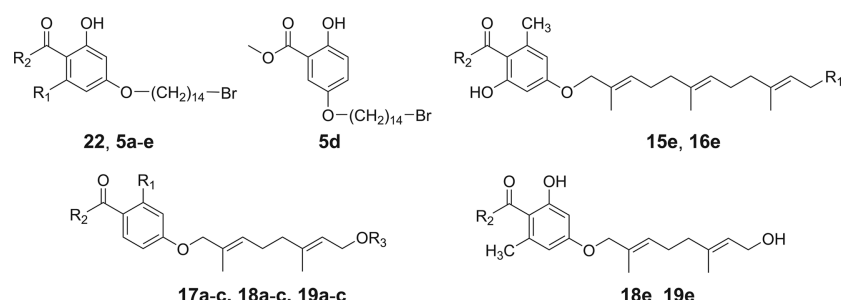

$\begin{array}{clllllll}\text { Cmpd } & \mathrm{R}_{1} & \mathrm{R}_{2} & \mathrm{R}_{3} & \mathrm{rTAO}^{a} & \text { T. b. brucei } & \mathrm{HEK}^{c} & \mathrm{SI}^{d} \\ \mathbf{2 2}^{c} & \mathrm{H} & \mathrm{H} & & 0.073 & 17.6 & & \\ \mathbf{5 a} & \mathrm{H} & \mathrm{OMe} & & 2.3 & \mathrm{NE} / 100 & \mathrm{NT} & \\ \mathbf{5 d} & & & & >5 & 8.1 & 28.6 & 3.5 \\ \mathbf{5 e} & \mathrm{Me} & \mathrm{OEt} & & >5 & 8.9 & 29.6 & 3.3 \\ \mathbf{1 5 e} & \mathrm{OAc} & \mathrm{OEt} & & >5 & 6.6 & 20.8 & 3.1 \\ \mathbf{1 6 e} & \mathrm{OH} & \mathrm{OH} & & 0.0031 & \mathrm{NE} / 100 & \mathrm{NT} & \\ \mathbf{1 7 a} & \mathrm{OH} & \mathrm{OMe} & \mathrm{Ac} & >5 & 19.3 & 31.8 & 1.7 \\ \mathbf{1 7 c} & \mathrm{Me} & \mathrm{OMe} & \mathrm{Ac} & >5 & 17.0 & 45.1 & 2.7 \\ \mathbf{1 8 a} & \mathrm{OH} & \mathrm{OH} & \mathrm{H} & 2.1 & \mathrm{NE} / 100 & \mathrm{NT} & \\ \mathbf{1 8 b} & \mathrm{F} & \mathrm{OH} & \mathrm{H} & 1.1 & \mathrm{NE} / 100 & \mathrm{NT} & \\ \mathbf{1 8 c} & \mathrm{Me} & \mathrm{OH} & \mathrm{H} & 0.92 & \mathrm{NE} / 100 & \mathrm{NT} & \\ \mathbf{1 8 e} & & \mathrm{OH} & \mathrm{H} & 2.4 & \mathrm{NE} / 100 & \mathrm{NT} & \\ \text { 19b } & \mathrm{F} & \mathrm{OMe} & \mathrm{H} & >5 & \mathrm{NE} / 100 & >100 & \\ \text { 19c } & \mathrm{Me} & \mathrm{OMe} & \mathrm{H} & 1.69 & \mathrm{NE} / 100 & >100 & \\ \text { 19e } & & \mathrm{OEt} & \mathrm{H} & >5 & \mathrm{NT} & \mathrm{NT} & \end{array}$

${ }^{a}$ Footnotes and control drugs: see Table 1. NE/100: not effective at $100 \mu \mathrm{M}$ (highest concentration tested).

Scheme 3. Synthesis of 4-Hydroxybenzoate Inhibitor $20 \mathrm{a}^{a}$<smiles>CCCCOC(=O)c1ccc(O)cc1OCC(C)=CCCC(C)=CCOC(C)=O</smiles><smiles>CC(=O)OC/C=C(\C)CC/C=C(\C)COC(=O)c1ccc(OC/C(C)=C/CC/C(C)=C/COC(C)=O)cc1O</smiles>

${ }^{a}$ Reagents and conditions. (i) $\mathrm{K}_{2} \mathrm{CO}_{3}$, acetone, $60{ }^{\circ} \mathrm{C}, 2 \mathrm{~h}$.

inhibitor 9e was more cytotoxic $\left(\mathrm{CC}_{50}=0.83 \mu \mathrm{M}\right)$ although this still yielded selectivity indexes of 64 and 230 toward $T$. brucei WT and AQP1-3 knockout strains, respectively. Other inhibitors with a lipocation tail displayed variable cytotoxicity against human cells $\left(\mathrm{CC}_{50}<1 \mu \mathrm{M}\right.$ for $6 \mathrm{a}, 7 \mathrm{a}-\mathrm{d}$; $\mathrm{CC}_{50}>20$ $\mu \mathrm{M}$ for 11c).

In summary, cationic 4-alkoxybenzoic acid derivatives are more potent TAO inhibitors than their benzaldehyde counterparts. The 2,4-dihydroxy-6-methyl carboxylic acid scaffold, in particular, gave the most potent TAO inhibitors (9e, 16e). Most of the 4-alkoxybenzoate-lipocation conjugates were also effective nanomolar range trypanocides. However, higher toxicity against human cells was observed resulting in lower selectivity indexes compared with previous series. Work is in progress to improve the drug-like properties of these series using alternative mitochondrion-targeting groups and prodrug strategies.

\section{ASSOCIATED CONTENT}

\section{Supporting Information}

The Supporting Information is available free of charge on the ACS Publications website at DOI: 10.1021/acsmedchemlett.8b00282.

Synthesis of compounds 4-21. Biology experimental protocols. Table S1. Tables 1 and 2 with SEM values (PDF)

\section{AUTHOR INFORMATION}

\section{Corresponding Authors}

*Phone: +44 (0) 1413303753. E-mail: Harry.De-Koning@ glasgow.ac.uk.

*Phone: +34 912587490. E-mail: dardonville@iqm.csic.es. ORCID $\odot$

Christophe Dardonville: 0000-0001-5395-1932

Author Contributions

${ }^{\perp}$ A.M.N. and G.U.E. contributed equally.

\section{Notes}

The authors declare no competing financial interest.

\section{ACKNOWLEDGMENTS}

Funding from the Spanish Ministerio de Economia y Competitividad (grant SAF2015-66690-R) is gratefully acknowledged. This research also received funding support from the Japan Society for the promotion of Science (JSPS grant17F17420).

\section{ABBREVIATIONS}

BSF trypanosome, bloodstream form trypanosome; DIAD, diisopropylazodicarboxylate; MTS, mitochondrion-targeting sequence; HB, hydrogen bond; RF, resistance factor; TAO, trypanosome alternative oxidase

\section{REFERENCES}

(1) Young, L.; Shiba, T.; Harada, S.; Kita, K.; Albury, M. S.; Moore, A. L. The alternative oxidases: Simple oxidoreductase proteins with complex functions. Biochem. Soc. Trans. 2013, 41, 1305-1311.

(2) Clarkson, A. B., Jr.; Bienen, E. J.; Pollakis, G.; Grady, R. W. Respiration of bloodstream forms of the parasite Trypanosoma brucei brucei is dependent on a plant-like alternative oxidase. J. Biol. Chem. 1989, 264, 17770-17776.

(3) Nakamura, K.; Fujioka, S.; Fukumoto, S.; Inoue, N.; Sakamoto, K.; Hirata, H.; Kido, Y.; Yabu, Y.; Suzuki, T.; Watanabe, Y.-i.; Saimoto, H.; Akiyama, H.; Kita, K. Trypanosome alternative oxidase, a potential therapeutic target for sleeping sickness, is conserved among Trypanosoma brucei subspecies. Parasitol. Int. 2010, 59, 560564.

(4) Menzies, S. K.; Tulloch, L. B.; Florence, G. J.; Smith, T. K. The trypanosome alternative oxidase: a potential drug target? Parasitology 2018, 145, 175-183.

(5) Yabu, Y.; Suzuki, T.; Nihei, C.; Minagawa, N.; Hosokawa, T.; Nagai, K.; Kita, K.; Ohta, N. Chemotherapeutic efficacy of ascofuranone in Trypanosoma vivax-infected mice without glycerol. Parasitol. Int. 2006, 55, 39-43.

(6) Yabu, Y.; Yoshida, A.; Suzuki, T.; Nihei, C.; Kawai, K.; Minagawa, N.; Hosokawa, T.; Nagai, K.; Kita, K.; Ohta, N. The efficacy of ascofuranone in a consecutive treatment on Trypanosoma brucei brucei in mice. Parasitol. Int. 2003, 52, 155-164.

(7) Nihei, C.; Fukai, Y.; Kita, K. Trypanosome alternative oxidase as a target of chemotherapy. Biochim. Biophys. Acta, Mol. Basis Dis. 2002, 1587, 234-239. 
(8) Saimoto, H.; Kido, Y.; Haga, Y.; Sakamoto, K.; Kita, K. Pharmacophore identification of ascofuranone, potent inhibitor of cyanide-insensitive alternative oxidase of Trypanosoma brucei. J. Biochem. 2013, 153, 267-273.

(9) Yabu, Y.; Suzuki, T.; Kita, K. Ascofuranone as a chemotherapeutic agent of African sleeping sickness. Baiosaiensu to Indasutori 2003, 61, 681-682.

(10) Minagawa, N.; Yabu, Y.; Kita, K.; Nagai, K.; Ohta, N.; Meguro, K.; Sakajo, S.; Yoshimoto, A. An antibiotic, ascofuranone, specifically inhibits respiration and in vitro growth of long slender bloodstream forms of Trypanosoma brucei brucei. Mol. Biochem. Parasitol. 1997, 84, 271-280.

(11) West, R. A.; Cunningham, T.; Pennicott, L. E.; Rao, S. P. S.; Ward, S. E. Toward More Drug Like Inhibitors of Trypanosome Alternative Oxidase. ACS Infect. Dis. 2018, 4, 592-604.

(12) West, R. A.; O’Doherty, O. G.; Askwith, T.; Atack, J.; Beswick, P.; Laverick, J.; Paradowski, M.; Pennicott, L. E.; Rao, S. P. S.; Williams, G.; Ward, S. E. African trypanosomiasis: Synthesis \& SAR enabling novel drug discovery of ubiquinol mimics for trypanosome alternative oxidase. Eur. J. Med. Chem. 2017, 141, 676-689.

(13) Shiba, T.; Kido, Y.; Sakamoto, K.; Inaoka, D. K.; Tsuge, C.; Tatsumi, R.; Takahashi, G.; Balogun, E. O.; Nara, T.; Aoki, T.; Honma, T.; Tanaka, A.; Inoue, M.; Matsuoka, S.; Saimoto, H.; Moore, A. L.; Harada, S.; Kita, K. Structure of the trypanosome cyanideinsensitive alternative oxidase. Proc. Natl. Acad. Sci. U. S. A. 2013, 110, $4580-4585$.

(14) Yabu, Y.; Minagawa, N.; Kita, K.; Nagai, K.; Honma, M.; Sakajo, S.; Koide, T.; Ohta, N.; Yoshimoto, A. Oral and intraperitoneal treatment of Trypanosoma brucei brucei with a combination of ascofuranone and glycerol in mice. Parasitol. Int. 1998, 47, 131137.

(15) Ebiloma, G. U.; Díaz Ayuga, T.; Balogun, E. O.; Abad Gil, L.; Donachie, A.; Kaiser, M.; Herraiz, T.; Inaoka, D. K.; Shiba, T.; Harada, S.; Kita, K.; de Koning, H. P.; Dardonville, C. Inhibition of trypanosome alternative oxidase without its $\mathrm{N}$-terminal mitochondrial targeting signal ( $\triangle \mathrm{MTS}-\mathrm{TAO})$ by cationic and non-cationic 4hydroxybenzoate and 4-alkoxybenzaldehyde derivatives active against T. brucei and T. congolense. Eur. J. Med. Chem. 2018, 150, 385-402.

(16) Fueyo González, F. J.; Ebiloma, G. U.; Izquierdo García, C.; Bruggeman, V.; Sánchez Villamañán, J. M.; Donachie, A.; Balogun, E. O.; Inaoka, D. K.; Shiba, T.; Harada, S.; Kita, K.; de Koning, H. P.; Dardonville, C. Conjugates of 2,4-Dihydroxybenzoate and Salicylhydroxamate and Lipocations Display Potent Anti-parasite Effects by Efficiently Targeting the Trypanosoma brucei and Trypanosoma congolense Mitochondrion. J. Med. Chem. 2017, 60, 1509-1522.

(17) Ott, R.; Chibale, K.; Anderson, S.; Chipeleme, A.; Chaudhuri, M.; Guerrah, A.; Colowick, N.; Hill, G. C. Novel inhibitors of the trypanosome alternative oxidase inhibit Trypanosoma brucei brucei growth and respiration. Acta Trop. 2006, 100, 172-184.

(18) Swamy, K. C. K.; Kumar, N. N. B.; Balaraman, E.; Kumar, K. V. P. P. Mitsunobu and Related Reactions: Advances and Applications. Chem. Rev. 2009, 109, 2551-2651.

(19) Chong, J. M.; Heuft, M. A.; Rabbat, P. Solvent Effects on the Monobromination of $\alpha, \omega$-Diols: A Convenient Preparation of $\omega$ Bromoalkanols. J. Org. Chem. 2000, 65, 5837-5838.

(20) Lizzul-Jurse, A.; Bailly, L.; Hubert-Roux, M.; Afonso, C.; Renard, P.-Y.; Sabot, C. Readily functionalizable phosphonium-tagged fluorescent coumarins for enhanced detection of conjugates by mass spectrometry. Org. Biomol. Chem. 2016, 14, 7777-7791.

(21) Matovu, E.; Stewart, M. L.; Geiser, F.; Brun, R.; Mäser, P.; Wallace, L. J. M.; Burchmore, R. J.; Enyaru, J. C. K.; Barrett, M. P.; Kaminsky, R.; Seebeck, T.; De Koning, H. P. Mechanisms of arsenical and diamidine uptake and resistance in Trypanosoma brucei. Eukaryotic Cell 2003, 2, 1003-1008.

(22) De Koning, H. P. Uptake of Pentamidine in Trypanosoma brucei brucei is Mediated by Three Distinct Transporters: Implications for Cross-Resistance with Arsenicals. Mol. Pharmacol. 2001, 59, 586-592.

(23) Jeacock, L.; Baker, N.; Wiedemar, N.; Mäser, P.; Horn, D. Aquaglyceroporin-null trypanosomes display glycerol transport defects and respiratory-inhibitor sensitivity. PLoS Pathog. 2017, 13, e1006307.

(24) Balogun, E. O.; Inaoka, D. K.; Shiba, T.; Kido, Y.; Nara, T.; Aoki, T.; Honma, T.; Tanaka, A.; Inoue, M.; Matsuoka, S.; Michels, P. A.; Harada, S.; Kita, K. Biochemical characterization of highly active Trypanosoma brucei gambiense glycerol kinase, a promising drug target. J. Biochem. 2013, 154, 77-84.

(25) Alkhaldi, A. A. M.; Martinek, J.; Panicucci, B.; Dardonville, C.; Zíková, A.; de Koning, H. P. Trypanocidal action of bisphosphonium salts through a mitochondrial target in bloodstream form Trypanosoma brucei. Int. J. Parasitol.: Drugs Drug Resist. 2016, 6, 23-34. 